Original Research Article

\title{
Comparative study of safety and efficacy profile of repaglinide and voglibose on targeting post prandial hyperglycemia in patients with newly diagnosed type II diabetes mellitus
}

\author{
Jyoti Bobde*, Rajesh Kadam, Deepak Bhosle
}

Department of Pharmacology, MGM Medical College, Aurangabad, Maharashtra, India

Received: 27 September 2018 Accepted: 25 October 2018

*Correspondence to:

Dr. Jyoti Bobde,

Email: drdeepakbhosle@ gmail.com

Copyright: (C) the author(s), publisher and licensee Medip Academy. This is an openaccess article distributed under the terms of the Creative Commons Attribution NonCommercial License, which permits unrestricted noncommercial use, distribution, and reproduction in any medium, provided the original work is properly cited.

\begin{abstract}
Background: In India the number of people with diabetes is increasing day-byday. Due to a sole "Asian Indian Phenotype," Indians develop diabetes an era earlier and have an earlier onset of complications. Therefore, it is essential to evaluate more effective treatment strategies at an earlier stage of disease progression.

Methods: The present study was prospective, open label, comparative, randomized, parallel group, single center study. Comparison of two post prandial active treatment groups over a period of 3 months. Sixty patients of either sex in the age group of 30-60years with newly diagnosed type II diabetes mellitus, with prandial blood glucose levels $>180 \mathrm{mg} \%$ and $<250 \mathrm{mg} \%$ at screening as per ADA. The effect of repaglinide and voglibose were observed on various parameters i.e. HbA1c, FBS, PBS, BMI.

Results: In repaglinide group the mean change in $\mathrm{HbA} 1 \mathrm{c}$ from baseline to 3 months was 8.05 to 7.04 (-1.01); on the other hand, in voglibose group from baseline to 3 months was 8.0 to 7.18 (-0.82). Whereas, FBS from 137.57 to 122.90 $(-16.67)$ in repaglinide group; in voglibose group from 139.87 to $125.13(-14.74)$. Repaglinide statistically highly significant than voglibose group in improving glycemic indices.

Conclusions: Though repaglinide and voglibose were equally effective in improving glycemic indices yet repaglinide showed better results in improving HbA1c, FBG, PBS as compared with voglibose. Repaglinide had minimal side effects as compared to voglibose.
\end{abstract}

Keywords: Repaglinide, Type II diabetes mellitus, Voglibose

\section{INTRODUCTION}

Diabetes mellitus is the single most important metabolic disease recognized worldwide as one of the leading causes of death and disability. ${ }^{1}$ It is characterized by hyperglycemia and altered metabolism of lipids, proteins and carbohydrates. It mainly occurs due to absolute or relative deficiency of insulin along with the component of insulin resistance. ${ }^{2}$

Currently, there is a growing interest in diabetes, as reported by International Diabetic Federation (IDF), an estimated 387 million people worldwide have diabetes in 2014 and this number is projected to reach a huge number of patients i.e. 592 million in 2035. While, IDF reported 66.8 million people of India are affected by diabetes in $2014 .^{3}$

Postprandial hyperglycemia is one of the earliest abnormalities of glucose homeostasis associated with type II DM and is markedly exaggerated in diabetic patients with fasting hyperglycemia. ${ }^{4}$ Recent studies have shown that postprandial hyperglycemia is more accurate predictor of HbA1c levels and cardiovascular mortality than fasting 
hyperglycemia, suggesting the control of postprandial hyperglycemia may be necessary to achieve HbA1c targets of $<7 \%$. ${ }^{5}$ This information has focused attention on post prandial glycemic control.

Voglibose is a $\alpha$-glucosidase inhibitors are widely used in the treatment of type II DM. They delay the terminal stage in the digestion and absorption of carbohydrate at the brush border of small intestine and thus having lowering effect on postprandial blood glucose and insulin level. ${ }^{6}$ In clinical trials in patients with diabetes mellitus also demonstrated that voglibose improves postprandial blood glucose levels. ${ }^{7}$ Voglibose may also facilitate $\alpha$ endogenous Glucagon-Like Peptide 1 (GLP-1) secretion, which has an inhibitory action on glucagon and is an insulinotropic hormone known to enhance insulin secretion and insulin sensitivity. These actions of voglibose are responsible for lowering fasting glucose levels too. ${ }^{8}$

Repaglinide is a meglitinide analogues are a new family of non-sulphonyl urea insulin secretagogues that stimulate insulin release by inhibiting ATP sensitive potassium channels of beta cell membrane via binding a receptor distinct from that of sulphonyl urea. Meglitinide analogues have a rapid onset and shorter duration of action; as a result, insulin secretion is stimulated to a greater extent within the first few minutes of their administration. Hence, they are effective in controlling post prandial surge of blood glucose levels. ${ }^{9}$

But no clinical studies comparing repaglinide and voglibose in a head to head comparison have been reported for reduction in fasting blood glucose, postprandial blood glucose and HbA1c level. With the above background and the clinical data available to date the present study was planned to compare and evaluate the effect of Repaglinide versus voglibose on postprandial blood glucose level and $\mathrm{HbA1c}$ in patients of newly diagnosed of type II DM.

\section{METHODS}

The design of this study was open label, randomized, parallel group, comparative and prospective clinical study. 60 diagnosed naive cases of patients of type II DM. They were randomly allocated into 2 groups of 30 each by chit method. Group I received repaglinide $1 \mathrm{mg}$ TDS. Group II received voglibose $0.3 \mathrm{mg}$ TDS.

\section{Inclusion criteria}

- Patients willing to participate and willing to give written informed consent prior to any study-related procedures and to comply with the requirements of the study protocol

- Patients of either sex having age group between 30 60 years

- Patients having newly diagnosed type II DM with prandial blood glucose levels $>180 \mathrm{mg} \%$ and $<250 \mathrm{mg} \%$.

\section{Exclusion criteria}

- Already on presence of type II DM

- $\quad$ Presence of Type II DM

- Requirement of insulin for diabetic control

- Known allergy to study drugs

- Deranged liver function test or kidney function test

- History of myocardial infarction or anaemia

- Pregnant and lactating women

- History of antidiabetic drug during past 3 months

- Presence of gastrointestinal diseases like inflammatory bowel disease, large hernias, intestinal obstruction, active ulcers, chronic pancreatitis.

\section{Investigations}

Blood sugar

Fasting and postprandial blood sugar were done on semi auto analyser by glucose oxidase /peroxidase (GOD / POD) method.

\section{Adverse event (AE)}

Patients withdrawn due to an AE were supposed to be followed until the AE has abated, or until a stable situation had been reached. All tests/examinations/ scheduled at study completion were supposed to be performed at premature termination/dropout. Drop outs were supposed to be replaced. All premature discontinuations, reasons and their causes were documented.

\section{Statistical analysis}

Paired and unpaired $t$ tests were used to measure the differences among the group. The data was analysed by paired $t$ test and unpaired t-test by using SPSS software 25 version.

\section{RESULTS}

\section{Baseline characteristics}

A total of 60 subjects were enrolled in this study. Patients were randomly divided into two groups of 30 each-

- $\quad$ Group I: repaglinide $1 \mathrm{mg}$ TDS.

- Group II: voglibose $0.3 \mathrm{mg}$ TDS.

Table 1: Age distribution.

\begin{tabular}{|lllll|}
\hline $\begin{array}{l}\text { Age in } \\
\text { years }\end{array}$ & Group I & \multicolumn{3}{c|}{ Group II } \\
\hline Gender & M & F & M & F \\
\hline $30-40$ & 4 & 5 & 6 & 5 \\
\hline $40-50$ & 5 & 6 & 5 & 4 \\
\hline $50-60$ & 6 & 4 & 7 & 3 \\
\hline \multirow{2}{*}{ Total } & 15 & 15 & 18 & 12 \\
& $(50 \%)$ & $(50 \%)$ & $(60 \%)$ & $(40 \%)$ \\
\hline
\end{tabular}


Table 1 shows the age and sex wise distribution of the subjects in both the groups under study. Both groups consisted of 30 subjects each. Group I consisted of 15 $(50 \%)$ male and $15(50 \%)$ female patients. Male patients in group II were $18(60 \%)$ and female were $12(40 \%)$.
Table 2 shows that there was a statistically highly significant decrease in HbAlc levels in group I (repaglinide) and group II (voglibose) after 3 months of treatment compared to baseline. However, the percentage reduction for group I (repaglinide) was more than that seen with group II (voglibose).

Table 2: Comparison of HbAlc in patients of Group I and II using paired t test.

\begin{tabular}{|c|c|c|c|c|c|}
\hline Group & & Mean \pm SD & $\begin{array}{l}\text { Percentage } \\
\text { reduction }\end{array}$ & p-value & $\begin{array}{l}\text { Significant } \\
\text { yes/no }\end{array}$ \\
\hline \multirow{2}{*}{ Group I (REPA) } & Before & $8.05 \pm 0.436$ & \multirow{2}{*}{$12.42 \%$} & \multirow{2}{*}{$<0.0001$} & \multirow{2}{*}{ Yes } \\
\hline & After 3 months & $7.04 \pm 0.516$ & & & \\
\hline \multirow{2}{*}{ Group II (VOGLI) } & Before & $8.0 \pm 0.407$ & \multirow{2}{*}{$10.25 \%$} & \multirow{2}{*}{$<0.0001$} & \multirow{2}{*}{ Yes } \\
\hline & After 3 months & $7.18 \pm 0.475$ & & & \\
\hline
\end{tabular}

If $p>0.05$ Not Significant, $p<0.05$ Significant and if $p<0.0001$ highly significant; Percentage reduction $=$ Mean difference/Baseline value $\mathrm{x} 100$

Table 3: Comparison of HbA1c in groups I and II using unpaired t test after 3 months of treatment.

\begin{tabular}{|llll|}
\hline Comparison of & t-value & p-value & Significant yes/no \\
\hline Group I (REPA) vs group II (VOGLI) & 1.09 & 0.27 & No \\
\hline (If P $>0.05$ Not Significant, $\mathrm{p}<0.05$ Significant) & &
\end{tabular}

Table 4: Comparison of FBS in patients of group I and II using paired t test.

\begin{tabular}{|c|c|c|c|c|c|}
\hline Group & & Mean \pm SD & $\begin{array}{l}\text { Percentage } \\
\text { reduction }\end{array}$ & p-value & $\begin{array}{l}\text { Significant } \\
\text { yes/no }\end{array}$ \\
\hline \multirow{2}{*}{ Group I (REPA) } & Before & $137.57 \pm 5.10$ & \multirow{2}{*}{$10.66 \%$} & \multirow{2}{*}{$<0.0001$} & \multirow{2}{*}{ Yes } \\
\hline & After 3 months & $122.90 \pm 4.33$ & & & \\
\hline \multirow{2}{*}{ Group II (VOGLI) } & Before & $139.87 \pm 7.09$ & \multirow{2}{*}{$10.50 \%$} & \multirow{2}{*}{$<0.0001$} & \multirow{2}{*}{ Yes } \\
\hline & After 3 months & $125.13 \pm 6.06$ & & & \\
\hline
\end{tabular}

If $p>0.05$ Not Significant, $p<0.05$ Significant and if $p<0.0001$ highly significant; Percentage reduction $=$ Mean difference/Baseline value $\mathrm{x} 100$

Table 5: Comparison of FBS in patients of group I and II using paired t test.

\begin{tabular}{|llll|}
\hline Comparison of & t-value & p-value & Significant yes/no \\
\hline Group I (REPA) vs group II (VOGLI) & 1.6416 & 0.1061 & No \\
\hline
\end{tabular}

(If $\mathrm{p}>0.05$ Not Significant, $\mathrm{p}<0.05$ Significant)

Table 6: Comparison of PBS in patients of group I and II by using student paired $t$ test.

\begin{tabular}{|lllll|l|}
\hline Group & & Mean \pm SD & $\begin{array}{l}\text { Percentage } \\
\text { reduction }\end{array}$ & p-value & $\begin{array}{l}\text { Significant } \\
\text { yes/no }\end{array}$ \\
\hline \multirow{2}{*}{ Group I (REPA) } & Before & $195.40 \pm 12.36$ & $10.14 \%$ & $<0.0001$ & Yes \\
\cline { 2 - 5 } Group II (VOGLI) & After 3 months & $175.57 \pm 9.92$ & & \multirow{2}{*}{ Yes } \\
\cline { 1 - 4 } & Before & $205.20 \pm 11.56$ & $9.89 \%$ & $<0.0001$ & \\
\hline
\end{tabular}

If $p>0.05$ Not Significant, $p<0.05$ Significant and if $p<0.0001$ highly significant; Percentage reduction $=$ Mean difference/Baseline value $\mathrm{x} 100$

Table 7: Comparison of post meal blood sugar in groups I and II using unpaired t test after 3 months of treatment.

\begin{tabular}{|llll||}
\hline Comparison of & t-value & p-value & Significant yes/no \\
\hline Group I (REPA) vs group II (VOGLI) & 3.1203 & 0.0028 & Yes \\
\hline
\end{tabular}

(If $\mathrm{p}>0.05$ Not Significant, $\mathrm{p}<0.05$ Significant) 
While comparing between group I (repaglinide) and group II (voglibose) from baseline verses after 3 months, there was no statistically significant difference observed in group I vs group II (Table 3).

Table 8: Comparison of BMI in patients of group I and II by using student paired t-test.

\begin{tabular}{|c|c|c|c|c|c|}
\hline Group & & Mean \pm SD & $\begin{array}{l}\text { percentage } \\
\text { changes }\end{array}$ & p-value & $\begin{array}{l}\text { Significant } \\
\text { Yes/no }\end{array}$ \\
\hline \multirow{2}{*}{ Group I (REPA) } & Before & $28.61 \pm 1.36$ & \multirow{2}{*}{$\uparrow 2.06 \%$} & \multirow{2}{*}{$<0.0001$} & \multirow{2}{*}{ Yes } \\
\hline & After 3 months & $29.40 \pm 1.40$ & & & \\
\hline \multirow{2}{*}{ Group II (VOGLI) } & Before & $28.62 \pm 1.16$ & \multirow{2}{*}{$\downarrow 2.20 \%$} & \multirow{2}{*}{$<0.0001$} & \multirow{2}{*}{ Yes } \\
\hline & After 3 months & $27.99 \pm 1.20$ & & & \\
\hline
\end{tabular}

If $p>0.05$ Not Significant, $p<0.05$ Significant and if $p<0.0001$ highly significant; Percentage reduction $=$ Mean difference/Baseline value $\mathrm{x} 100$

Table 9: Comparison OF BMI in group I and group II using unpaired t test.

\begin{tabular}{|llll|}
\hline Comparison of & t-value & p-value & Significant yes/no \\
\hline Group I (REPA) vs group II (VOGLI) & 4.14 & $<0.0001$ & Yes \\
\hline
\end{tabular}

Table 10: Adverse drug reactions reported by the patients in both the groups.

\begin{tabular}{|lllll|}
\hline Groups & Hypoglycemia & Diarrhea & Nausea/vomiting & Abdominal distention/ Flatulence \\
\hline Group I (REPA) & 3 & Nil & Nil & Nil \\
\hline Group II (VOGLI) & Nil & 2 & 1 & 3 \\
\hline Total & 3 & 2 & 1 & 3 \\
\hline
\end{tabular}

There was a statistically significant decrease in fasting blood glucose levels in group I (repaglinide) and group II (voglibose) after 3 months of treatment compared to baseline. However, the percentage reduction for group I (repaglinide) was more than that seen with group II (voglibose) (Table 4).

While comparing between group I (repaglinide) and group II (voglibose) from baseline verses after 3 months, there was no statistically significant difference observed in group I Vs group II (Table 5).

Table 6 shows that there was a statistically highly significant decrease in post meal blood glucose levels in group I (REPA) group II (VOG) after 3 months of treatment compared to baseline. However, the Percentage reduction for group I (repaglinide) was more than that seen with group II (voglibose).

While comparing between group I (repaglinide) and Group II (voglibose) from baseline verses after 3 months, there decrease in post meal blood sugar level was statistically significantly different between two groups (Table 7).

Table 8 depicts that there was a statistically highly significant increase in body mass index (BMI) levels in group I, and statistically highly significant decrease in group II after 3 months of treatment compared to baseline.
While comparing between group I (repaglinide) and Group II (voglibose) from baseline verses after 3 months, there was statistically highly significant difference after 3 months group I vs. group II the groups in BMI levels (Table 9).

Table 10 shows the hypoglycemia was seen in 3 patients in group I while diarrhea, nausea/vomiting and abdominal distention/flatulence were reported in 2,1 , and 3 patients respectively in group II.

\section{DISCUSSION}

Diabetes mellitus is the most important metabolic disease, characterized by hypoglycemia along with altered metabolism of lipids, proteins and carbohydrates. It mainly occurs due to absolute or relative deficiency of insulin along with the component of insulin resistance. ${ }^{10}$

The latest American Diabetes Association guidelines suggest that lowering HbAlc level to below or around 7\% reduces the risk of microvascular and macrovascular complications of diabetes and, that if it is implemented soon after the diagnosis of diabetes, it benefits in long-term reduction of such complications. Therefore, a reasonable HbAlc goal for many adults is $<7 \% .^{11}$ Moreover, The United Kingdom Prospective Diabetes (UKPD) study showed that for every $1 \%$ reduction in HbAlc levels, there 
was an average reduction in micro-vascular complications of $21 \%$ while the risk of myocardial infarction and sudden death were reduced by $16 \% .^{12}$

Post-Prandial Hyperglycemia is the major determinant of HbAlc levels than fasting hyperglycemia. Considerable data also have been accumulated indicating that elevated post prandial glucose levels, even in the absence of fasting hyperglycemia, increase HbAlc level and the risk for cardiovascular disease (CVD). So, by reducing post Prandial hyperglycemia HbA1c levels can be controlled, thereby reducing various microvascular and macrovascular complications. Various studies have shown reduction in post-prandial hyperglycemia significantly reduces $\mathrm{HbA1c}$ levels in type $2 \mathrm{DM}$ in patients. So, when treating frank diabetes mellitus or impaired glucose tolerance postprandial hyperglycemia level is a major factor which requires aggressive control. ${ }^{13-15}$

Currently, five groups of drugs used in the treatment of Type 2 DM that primarily target postprandial hyperglycemia which are short acting insulins, meglitinides, DPP4 inhibitors, alpha glucosidase inhibitors and GLP-1 analogues. ${ }^{16,17}$

Voglibose is a more potent and tolerant a glucosidase inhibitor (AGI) as compared to Acarbose and Miglitol. This is because, voglibose selectively inhibits enzymes responsible for digestion of disaccharides but spares alpha amylase, which is responsible for digestion of starch a polysaccharide. While, acarbose also inhibits alpha amylase enzyme in addition to disaccharides causing increased amounts of starch in the small intestine. This undigested and unabsorbed starch in feces is responsible for gastrointestinal side effects (gases, flatulence and abdominal distention). ${ }^{18}$

The loss of first phase of insulin secretion response, along with insulin resistance, results in development of PostPrandial Hyperglycemia (PPHG). Meglitinide analogues Primarily help to improve first phase of insulin secretion. They have a rapid onset and shorter duration of action; as a result, insulin secretion is stimulated to a greater extent within the first few minutes of their administration before meal, which is responsible for increased levels of first phase of insulin. Hence, they are effective in controlling postprandial surge of blood glucose levels. ${ }^{19}$

But there was no head to head studies comparing Repaglinide and voglibose. So, the study was planned to study the safety and efficacy profile of repaglinide and voglibose on targeting post prandial hyperglycemia in patients with newly diagnosed type II diabetes mellitus. The parameters measured in our study were FBS, PBS, $\mathrm{HbA} 1 \mathrm{c}$ and BMI at the start and end of the study.

Results for the repaglinide group, in our study for the parameter mean Fasting Blood Sugar (FBS), there was decrease in mean baseline value from $137.57 \pm 5.10$ to $122.90 \pm 4.33 \mathrm{mg} / \mathrm{dl}$ after 12 weeks of Repaglinide $1 \mathrm{mg}$ TDS treatment. The reduction was statistically highly significant $(\mathrm{p}<0.0001)$. This finding is supported by the study done by Ma $\mathrm{J}$ et al, which showed that fasting blood glucose was decreased after 3 months therapy in repaglinide group from $138.96 \pm 3.06$ to $116.28 \pm 2.52 \mathrm{mg} / \mathrm{dl}$, which was also statistically significant (Table $4, \mathrm{p}<0.01$ ). ${ }^{20}$

In present study for the parameter mean prandial blood sugar (PBS), there was decrease in mean baseline value from $195.40 \pm 12.36$ to $175.57 \pm 9.92 \mathrm{mg} / \mathrm{dl}$ after 12 weeks of treatment with repaglinide $1 \mathrm{mg}$ TDS. The reduction was statistically highly significant $(p<0.0001)$. This finding is supported by the study done by Fang F et al, which suggested that patients treated with repaglinide showed reduction in PBS from $206.1 \pm 4.08$ to $180.4 \pm 3.08$, which was also statistically significant (Table 6, $\mathrm{p}<0.01) .^{21}$

In present study for the parameter mean $\mathrm{HbAlc}$, there was decrease in mean baseline value from $8.05 \pm 0.04$ to $7.04 \pm 0.51 \%$ after 12 weeks of Repaglinide lmg TDS treatment. The reduction was statistically highly significant $(\mathrm{p}<0.0001)$. This finding is supported by the study done by Ma $\mathrm{J}$ et al, which showed that HbAlc was decreased with repaglinide therapy from $7.42 \pm 0.13 \%$ to $6.28 \pm 0.09 \%$, which was also statistically significant (Table $2, \mathrm{p}<0.01){ }^{22}$

And lastly for the repaglinide group, in present study for the parameter mean BMI, there was increase in mean baseline value from $28.61 \pm 1.36$ to $29.40 \pm 1.40 \mathrm{~kg} / \mathrm{m}^{2}$ after 12 weeks of Repaglinide lmg TDS treatment. This increase was statistically highly significant (Table $8, \mathrm{p}<0.0001$ ). In a multicenter, double-blind, placebo-controlled study, aimed to assess the efficacy and safety of repaglinide compared with placebo in type 2 diabetes patients, Goldberg et al, demonstrated only a small non-significant increase in body weight. ${ }^{23}$

Now for the voglibose group, in our study for the parameter mean Fasting Blood sugar (FBS) there was decrease in mean baseline value from $139.87 \pm 7.09$ to $125.13 \pm 6.06 \mathrm{mg} / \mathrm{dl}$ after 12 weeks of voglibose $0.3 \mathrm{mg}$ TDS treatment. This reduction was statically highly significant ( $\mathrm{p}<0.0001)$. This finding is supported by the study done Lee MY, et al, which showed that Fasting blood glucose was decreased after 3- month therapy in voglibose group from $158.4 \pm 6.26$ to $134.4 \pm 5.18 \mathrm{mg} / \mathrm{dl}$, which was also statistically significant (Table $4, \mathrm{p}<0.01) .{ }^{24}$

In present study for the parameter mean prandial blood glucose (PBS), there was decrease in mean baseline value from $205.20 \pm 11.56$ to $184.90 \pm 13.04 \mathrm{mg} / \mathrm{dl}$ after 12 weeks of treatment with voglibose $0.3 \mathrm{mg}$ TDS. This reduction was statistically highly significant $(\mathrm{p}<0.0001)$. This finding is supported by the study done by Lee MY et al, which showed that patients treated with voglibose showed reduction in PBS from 224.18 \pm 70.07 to $193.01 \pm 55.39 \mathrm{mg} / \mathrm{dl}$ which was also statistically significant (Table 6, p<0.01). 
In present study for the parameter mean $\mathrm{HbA} 1 \mathrm{c}$, there was decrease in mean baseline value from $8.0 \pm 0.407$ to $7.18 \pm 0.475 \%$. After 12 weeks of voglibose $0.3 \mathrm{mg}$ TDS treatment. This reduction was statistically highly significant $(\mathrm{p}<0.0001)$. This finding is supported by the study done by Hitoshi Sugihara et al, which showed that HbA1c was decreased by voglibose therapy (Table 2, $\mathrm{p}<0.01)^{25}$

And lastly for the voglibose group, in our study for the parameter mean $\mathrm{BMI}$, decrease in mean baseline value from $28.62 \pm 1.16$ to $27.99 \pm 1.20 \mathrm{~kg} / \mathrm{m}^{2}$ after 12 weeks of voglibose $0.3 \mathrm{mg}$ TDS treatment. This increase was statistically highly significant $(\mathrm{p}<0.0001)$. This finding is supported by the study done by Hitoshi $\mathrm{S}$ et al, which showed that BMI was decreased after 3-month therapy in voglibose group from $28.9 \pm 5.3$ and $27.6 \pm 4.9 \mathrm{~kg} / \mathrm{m}^{2}$, it was also statistically significant (Table $8, \mathrm{p}<0.01){ }^{25}$

When the values of both the groups after 12 weeks of therapy was compared by unpaired t-test, there was no statistically significant difference in the levels of FBS and HbA1c however PBS levels showed a statistically highly significant difference. But when Percentage reductions of FBS, PBS and HbA1c were compared, the percentage reduction by repaglinide were more as compared to the percentage reduction for these Parameters by voglibose. This shows that Repaglinide is more efficacious than voglibose in reducing all these values. But there is a concern about repaglinide that it increases BMI.

In present study, in repaglinide group $3(10 \%)$ patients reported hypoglycemia. This is supported by the study done by Guay DR et al. In his study the most frequently reported adverse events were hypoglycemia (16\%), and upper respiratory tract infections (10\%) with Repaglinide treatment. $^{26}$ Fujisawa $\mathrm{T}$ et al, showed that the most common reported side effect of voglibose is abdominal flatulence, and other gastrointestinal side effects too. ${ }^{27} \mathrm{In}$ present study, in voglibose group $2(6.66 \%)$ patients reported diarrhea, $1(3.33 \%)$ patient reported nausea and vomiting and $3(10 \%)$ patients reported abdominal distention and flatulence over the course of 12 weeks duration. But no one left the study because of occurrence of adverse drug reactions.

In present study, both the drugs showed significant improvement in the study parameters. But the study has some limitations, like, it had small sample size and short duration of action so further studies with larger sample size and longer duration are needed to confirm the results of our present study. Also, the cost effectiveness of the drugs needs to be concerned as both the drugs were expensive and were used TDS.

\section{CONCLUSION}

In summary after 12 weeks of treatment with Repaglinide and voglibose, there statistically highly significant reduction in FBS, PBS, HbA1c and BMI levels in both groups when compared (by paired t test) to their baseline levels. When the values of both the groups after 12 weeks of therapy were compared by unpaired t-test, there was no statistically significant difference in the levels of FBS and HbA1c however PBS levels showed a statistically significant difference, while BMI levels showed a statistically highly significant difference. When percentage values compared, repaglinide showed higher percentage reduction than voglibose for all the parameters (FBS, PBS, $\mathrm{HbA1c}$ and BMI).

Authors conclude that both repaglinide and voglibose elicited a clinically meaningful decrease in $\mathrm{HbA} 1 \mathrm{c}$, fasting blood sugar and post meal blood sugar sustained throughout 12 weeks of treatment in drug-naive patients with type $2 \mathrm{DM}$. Further long-term trials evaluating the effects of this treatment on the microvascular and macrovascular diseases that complicate the clinical course of type 2 diabetes would be of interest.

Funding: No funding sources Conflict of interest: None declared

Ethical approval: The study was approved by the Institutional Ethics Committee

\section{REFERENCES}

1. Zimmet PZ. Diabetes epidemiology as a tool to trigger diabetes research and care. Diabetologia. 1999 Apr 1;42(5):499-518.

2. Boden G. Fatty acids and insulin resistance. Diabetes Care. 2010 Oct; 33(10):394-5.

3. International Diabetes Federation Atlas. 6th ed. 2014.

4. American Diabetes Association. postprandial blood glucose. Diabetes Care. 2001 Apr;24(4):775-8.

5. Avignon A, Radauceanu A, Monnier L. Nonfasting plasma glucose is a better marker of diabetic control than fasting plasma glucose in type 2 diabetes. Diabetes care. 1997 Dec 1;20(12):1822-6.

6. Adiyodi JR. Acarbose: Revolutionising treatment of NIDDM. Diabetes update. 1999 Jun:18-31.

7. Ikeda H, Horii S, Matsuo T. Diabetes Res. Clin Pract 1985;(Suppl.):661.

8. Shinozaki K, Suzuki M, Ikebuchi M, Hirose J, Harano Y, Harano Y. Improvement of insulin sensitivity and dyslipidemia with a new $\alpha$-glucosidase inhibitor, voglibose, in nondiabetic hyperinsulinemic subjects. Metabolism Clin Experimental. 1996 Jun 1;45(6):7317.

9. Landgraf R. Meglitinide analogues in the treatment of type 2 diabetes mellitus. Drugs Aging. 2000 Nov $1 ; 17(5): 411-25$.

10. Maitra A, Abbas AK. Endocrine system. In: Kumar V, Fausto N, Abbas AK (eds). Robbins and Cotran Pathologic basis of disease. 7th ed. Philadelphia, Saunders;2005:1156-1226.

11. Inzucchi SE, Bergenstal RM, Buse JB, Diamant M, Ferrannini E, Nauck $M$, et al. Management of hyperglycemia in type 2 diabetes: a patient-centered approach: position statement of the American 
Diabetes Association (ADA) and the European Association for the Study of Diabetes (EASD). Diabetes Care. 2012;35:1364-79.

12. UKPDS. Intensive blood-glucose control with sulphonylureas or insulin compared with conventional treatment and risk of complications in patients with type 2 diabetes (UKPDS 33). Lancet. 1998;352(9131): 837-853.

13. Avignon A, Radauceanu A, Monnier L. Nonfasting plasma glucose is a better marker of diabetic control than fasting plasma glucose in type 2 diabetes. Diabetes Care. 1997 Dec 1;20(12):1822-6.

14. Hanefeld M, Fischer S, Julius U, Schulze J, Schwanebeck U, Schmechel H, et al. Risk factors for myocardial infarction and death in newly detected NIDDM: the diabetes intervention study, 11-year follow-up. Diabetologia. 1996 Nov 1;39(12):1577-83.

15. Nihalani KP, Shembalkar JP. New modalities in treatment of diabetes. Diabetes Update. 1999:12-17.

16. Nathan DM, Buse JB, Davidson MB, Ferrannini E, Holman RR, Sherwin R, et al. Medical management of hyperglycemia in type 2 diabetes: a consensus algorithm for the initiation and adjustment of therapy: a consensus statement of the American Diabetes Association and the European Association for the Study of Diabetes. Diabetes Care. 2009 Jan 1;32(1):193-203.

17. Gerich JE. Clinical significance, pathogenesis, and management of postprandial hyperglycemia. Arch Internal Med. 2003 Jun 9;163(11):1306-16.

18. Hu S, Wang S, Fanelli B, Bell PA, Dunning BE, Geisse $S$, et al. Pancreatic $\beta$-cell K ATP channel activity and membrane-binding studies with nateglinide: a comparison with sulfonylureas and repaglinide. J Pharmacol Experimental Therapeut. 2000 May 1;293(2):444-52.

19. Rosenstock J, Hassman DR, Madder RD, Brazinsky SA, Farrell J, Khutoryansky N, et al. Repaglinide versus nateglinide monotherapy: a randomized, multicenter study. Diabetes Care. 2004 Jun 1;27(6):1265-70.

20. Ma J, Liu LY, Wu PH, Liao Y, Tao T, Liu W. Comparison of metformin and repaglinide monotherapy in the treatment of new onset type 2 diabetes mellitus in China. J Diabetes Res. 2014;2014.

21. Fang F, Gon Y, Lj C, Li J, Tian H, Huang W, et al. Comparison of repaglinide and metformin monotherapy as an initial therapy in Chinese patients with newly diagnosed type 2 diabetes mellitus. Eur J Endocrinol. 2014 Jun;170(6):901-8.

22. Harris MI, Klein R, Welborn TA, Knuiman MW. Onset of NIDDM occurs at least 4-7 yr before clinical diagnosis. Diabetes Care 1992. Jul;15(7):815-9.

23. Goldberg RB, Einhorn D, Lucas CP, Rendell MS, Damsbo P, Huang WC, et al. A randomized placebocontrolled trial of repaglinide in the treatment of type 2 diabetes. Diabetes Care. 1998 Nov 1;21(11):1897903.

24. Lee MY, Choi DS, Lee MK, Lee HW, Park TS, Kim $\mathrm{DM}$, et al. Comparison of acarbose and voglibose in diabetes patients who are inadequately controlled with basal insulin treatment: randomized, parallel, openlabel, active-controlled study. J Korean Med Sci. 2014 Jan 1;29(1):90-7.

25. Hitoshi $S$, Naeao $M$, jjarada $T$, Nakajima $Y$, Inagaki $\mathrm{K}$, Okaiima F. et al. Comparison of three a-glucosidase inhibitors for glycemic control and bodyweight reduction in Japanese patients with obese type 2 diabetes. J Diabetes lnvestig. 2014 Mar23;5(2):20612.

26. Guay DR. Repaglinide, a novel, short-acting hypoglycemic agent for type 2 diabetes mellitus. Pharmacotherapy: J Human Pharmacol Drug Therapy. 1998 Nov 12;18(6):1195-204.

27. Fujisawa $T$, Ikegami $H$, Inoue $K$, Kawabata $Y$, Ogihara T. Effect of two $\alpha$-glucosidase inhibitors, voglibose and acarbose, on postprandial hyperglycemia correlates with subjective abdominal symptoms. Metabolism. 2005 Mar 1;54(3):387-90.

Cite this article as: Bobde $\mathrm{J}$, Kadam R, Bhosle D. Comparative study of safety and efficacy profile of repaglinide and voglibose on targeting post prandial hyperglycemia in patients with newly diagnosed type II diabetes mellitus. Int J Basic Clin Pharmacol 2018;7:2325-31. 